\title{
Rozporuplný Arne Naess - několik poznámek k zakladateli hlubinné ekologie II.
}

\section{Bohuslav Binka}

\author{
Envigogika 2007/II/3 - Recenzované články/ Reviewed Papers \\ Publikováno/Published 30. 12. 2007 \\ DOI: http://dx.doi.org/10.14712/18023061.21
}

\begin{abstract}
Abstrakt:
Druhá část textu, který zkoumá základní charakteristiky filosofického konceptu Arne Naesse, přibližuje jejich spojitost $s$ osobností autora i vybranými rysy historického vývoje evropské kultury první poloviny 20. století a snaží se poukázat na jisté rozporuplné tendence Naessovy ekosofie $\mathrm{T}$.
\end{abstract}

\section{Klíčová slova:}

Hlubinná ekologie, Arne Naess, racionální, emocionální, vcítění se, pluralita, filosofická východiska, obsahová analýza, mentální mapa, ontologický dualismus

\begin{abstract}
:
The aim of this text is to examine some basic characteristics of Arne Neass' philosophical concept, examines their connection with the authors' personality and selected outlines of historical development of European culture in the first half of 20th century and prove the philosophical grounds upon which Arne Neass' deep ecology stands preexisted independently of Neass. It endeavors to refer to certain inconsistent tendencies of Neasses' ecosophy T. Therefore the text is a direct polemic with the Neass' interpretation of deep ecology in the writings of leading Czech environmentalist professor Hana Librová and professor Erazim Kohák. After the historic-psychological discussion of the genealogy of Arne Neass' philosophical opinions, the focal point of argumentation shifts to the analysis of a selection of Neass' texts. In total three studies of the ontological recourses and mental maps of Neass' texts prove his deep ecology consists of two very contradictory tendencies: a humanistic and enlightenment tendency and the tendency of the emotionally and religiously antirational.
\end{abstract}

\section{Key words:}

Deep ecology, Arne Neass, rational, emotional, plurality, philosophical grounds, content analysis, mental map, ontological dualism 


\section{Analýza textů}

V následující práci bych rád navázal na rozbor Naessova osobního a filozofického vývoje, publikovaný $v$ předešlém článku, podrobnou analýzou jeho textů. Nejprve si dovolím upřesnit, z kterých částí Naessova díla vybírám texty k analýze. Naess publikoval dvě hlubinně ekologicky orientované knihy - Ecology, Community and Lifestyle ${ }^{1}$ a Is It Painful to Think $?^{2}$ a několik knih s hlubinnou ekologií souvisejících, mezi kterými je pro náš účel nejvýznamnější Gándhí and Group Conflict. ${ }^{3}$ Navíc se spoluautorsky podílel na, pro hlubinnou ekologii tak zásadní knize, jako je Deep Ecology. ${ }^{4}$ Devalla a Sessionse. Stal se klíčovým autorem sborníků: Thinking Like a Mountain, ${ }^{5}$ Deep Ecology for the 21 st Century, ${ }^{6}$ Deep Ecology, ${ }^{7}$ Deep-Long Range Ecology Movement a publikoval v časopisech environmentálně zaměřených ${ }^{8}$ The Trumpeter $^{9}$ Earth First!, ${ }^{10}$ The Ecologist, ${ }^{11}$

${ }^{1}$ Viz Naess, A. Ecology, Community and Lifestyle. Cambridge : Syndicate of Press of the University of Cambridge, 1989. ISBN 0-521-34873-0. Znovu upozorňuji, že tato kniha není původním autorským dílem Naessovým - přestože jeho podíl je zásadní - ale výborem, který uspořádal David Rothenberg.

2 Naess, A., Rothenberg, D. Is It Painful to Think? : Conversations with Arne Naess. 1. vyd. London: University of Minnesota Press, 1993. ISBN 0-8166-2151-9. Ani tato kniha není čistě Naessovým počinem - i zde vyšel impuls od Davida Rothenberga - není to nepřímým důkazem Naessovy ustálenosti a vakua potřeb čehosi nového?

3 Viz Naess, A. Gándhí and Groupe Conflict : An Exploration of Satyagraha - Theoretical Background. 1. vyd. Oslo : Universitetsforlaget, 1974. ISBN 8200089215.

4 Devall, B., SESSIONS, G. Deep Ekology : Living as if Nature Matterd. Salt Lake City : Peregrine Smith Books, 1985. ISBN 0-87905-158-2. Zde chci upozornit na skutečnost, že přes veškerý význam přikládaný této knize mi pro studium hlubinně ekologických postojů autorů jako je např. Devall připadá vhodnější kniha Simple in Means, Rich in Ends : Practicing Deep Ecology - inspirovaná, jak je patrno již z názvu, právě Naessovým dílem (Devall využil Naessova rozhovoru z roku 1982 Simple in Means, Rich in Ends : A Conversation with Arne Naess). Tato kniha podává celkem vyčerpávající popis "životní pouti" z ochranářského hnutí vzešlých, akademických environmentalistů. Doplňkem mưže být Manesova kniha Green Rage : Radical Environmentalism and the Unmaking of Civilization, která podává př́běh aktivistického proudu hlubinné ekologie. Z tohoto srovnání je zřejmé, že jak akademičtí, tak aktivističtí hlubinní ekologové z Naesse - a zejména jeho Gándhíovské části významně čerpají. Viz Devall, B. Simple in Means Rich in Dnes : Practicing Deep Ecology. Salt Lake City : Peregrine Smith Books, 1988. ISBN 0-87905-294-5.; Manes, Ch. Green Rage : Radial Environmentalism and the Unmaking of Civilization. Boston : Little, Brown and Copany, 1990. ISBN 0-316-54513-9.

5 Žádný z těchto sborníků Naess sám needitoval, přesto je ve všech jedním ze zásadních autorů - i to něco vypovídá o jeho postavení v rámci hlubinné ekologie. Viz Seed, J., Macy, J., Fleming, P., Naess, A. Thinking Like a Mountain : Towards a Council of all Beings. Philadelphia : New Society Publisher, 1988. ISBN 0-86571-133-X.

${ }^{6}$ Viz Sessions, G.Ecocentrism and the Antropocentric Detour. In Deep Ecology for the 21st Century : Reading on the Philosophy and the Practice of New Environmentalism. Boston : Shambhala, 1995. ISBN 1-570-62049-0. $V$ této knize je Naesovi věnována celá třetí část nesená $v$ případě textů o Naessovi ve velmi oslavném duchu. Výběr samotných Naessových textů je však reprezantativní nalezneme tu zásadní texty jako Self-Realization an Ecological Approach to Being in the World (s. 225-239), Ecosophy and Gestalt Ontology (s. 240-245), The Place of Joy in a World of Fact (s. 249-258) a velmi zajímavé dosud nepublikované texty jako Deepness of Questions and the Deep Ecology Movement (s. 204-212) a The Deep Ecology "Eight Points" Revisited (s. 213-221).

7 Viz Deep ecology. Edited by M. Tobias. San Diego : Avant Books, 1985. ISBN 1570620492.

8 Dalším důkazem významu Naesse pro hlubinně ekologické hnutí, ale též jeho sourodost $s$ ním, je počet článků Naesse samotného a článků týkajících se významně jeho osoby, tzn. článků, ve kterých se jméno Naess objevuje $v$ nadpisu a zároveň je Naessova hlubinná ekologie významně př́tomna $\checkmark$ článku samotném. Tento poměr je např́klad v časopise Trumpeter od roku 1990 10:11, v časopise Earth First! dokonce 3:48.

9 Do časopisu The Trumpeter přispěl Naess 18 články, mezi kterými nalezneme články zásadního významu - Sustainable Development and the Deep Long-Range Ecology Movement z roku 1988, How Should Supporters of Deep Ecology Movement Behave in Order to Affect Society and Culture z roku 1993, Deep Ecology in the Line of Fire z roku 1995, Heidegger, Postmodern Theory and Deep Ecology 
Resurgence ${ }^{12}$, Environmental Ethics ${ }^{13}$, politologických a filozofických Inquire ${ }^{14}$, Methodology and Science a okrajově též v časopisech jako Ten Direction, PanEcology, Philosophia, či Appalachia. V roce 2005 pak vychází desetisvazkový výbor podrobně mapující Naessovu filozofickou i hlubinně-ekologickou dráhu.

Výběr z tohoto nepřeberného množství textů jistě nemůže být jednoduchý - text musí být významný pro další vývoj ekologického hnutí15 (to všechny pod čarou uvedené texty, pokud není uvedeno jinak, splňují), zároveň typický - a typizující - pro samotného autora ( $v$ tomto prípadě Naesse) a navíc musí zapadat od mozaiky dvou dalších vybraných textů tak, aby poskytl co nejlepší možné východisko pro rozbor. Na základě těchto kritérií vybírám následující text z vlivného sborníku "Myslet jako hora" (1993): ${ }^{16}$

„To co chci nyní ríci víceméně svým vlastním způsobem, by se dalo zhruba shrnout do následujících šesti bodů:

\section{Podceňujeme se. Zdůrazňuji ,já'. Máme tendenci si ho plést z úzkým ego.}

2. Lidská přirozenost je taková, že budeme-li dostatečně a všestranně vyzrálí, nemůžeme se vyhnout ,identifikování se všemi žijícími bytostmi, krásnými či ošklivými, velkými či malými, vnímavými či nevnímavými. Svůj pojem ,identifikování objasním později.

3. V tradičním pojetí cesta ke zralosti ,já' vede třemi stadii - od ega k sociálnímu ,já' a od sociálního, já' k metafyzickému, já'. V tomto pojetí je však velice přehlížena příroda náš domov, naše bezprostřední okolí, k němuž náležíme jako děti - a naše ztotožnění s žijícími lidmi. Proto pokusně zavádím pojem, ekologické já'. Od samotného počátku mưžeme být $v$ přírodě, $z$ prrírody a pro př́rodu. Společnost a lidské vztahy jsou důležité, ale naše ,já' je ve vztazích, které ho vytvářejí, mnohem bohatší. Mezi tyto kontakty nepatří jen vztahy $\mathrm{k}$ lidem a $\mathrm{k}$ lidskému společenství, ale i vztahy, které máme k mnohem většímu společenství - ke společenství všech bytostí.

z roku 1997; dále články, které jsou velmi specifické pro Naessův styl či koncept - např. To Grow up or to Get to be More Nature? Z roku 1992 či Mountains and Mythology z roku 1995, či konečně Legend, Deprived and Also College Students z roku 2001, ve kterém se Naess kriticky - ale jako vždy vstřícně - postaví k radikálnímu postoji hlubinné ekologie. $V$ tomto článku se též po dlouhých patnácti letech přiblíží postoji Bookchina. Skutečnou kritiku hlubinné ekologie však ani zde nenalezneme př́značný je i vybraný "radikální" hlubinný ekolog Stan Rowe - neznámá to postava v hlubinně ekologickém hnutí.

10 Do časopisu Earth First! přispíval Naess jen zřídka, k zásadnějším článkům patří snad jen The Deepness of Deep Ecology z roku 1989, ve kterém Naess také připouští jistou autoritativnost $v$ části hlubinně ekologického hnutí. Je to však jen nesmělý náznak. Viz Naess, A. The Deepness of Deep Ecology. Earth First! : The Radical Environmental Journal. 1989, roč. 10, č. 2, s. 7. ISSN 1055-8411.

${ }^{11}$ Viz napríklad Naess, A. Intuition, Intristic Value, and Deep Ekology : Comments on an Article by Warwick Fox. The Ecologist. 1984, roč. 14, č. 5/6, s. 201-203. ISSN 0261-3131.; či o něco významější Naess, A. Deep Ecology and Ultimate Premisis. The Ecologist. 1988, roč. 18, č. 4/5, s. 128-131. ISSN 0261-3131. Jak je žrejmé, The Ecologist nebyl "domovským" časopisem Naesse.

12 Mezi zásadní Naessovy články publikované v časopisu Resurgence patří The Basics of Deep Ecology z roku 1988 - i tyto články však patří spíše k okrajovým rozsahem i významem.

${ }^{13}$ Environmental Ethics stojí svým významem pro environmentální hnutí, či spíše pro jeho teoretiky velmi vysoko, je považován za jeden z nejprestižnějších časopisů týkající se ekologické etiky. Naess $\checkmark$ něm publikoval pouze několikrát, tyto články jsou však významné. Viz např. Naess, $A$. A Defense of the Deep Ecology Movement. Environmental Ethics. 1984, roč. 6, č. 3, s. 265-270. ISSN 0163-4275. 14 Zásadní časopis pro Naesse myslitele a analytika. Význam prvního díla hlubinné ekologie The Shallow and the Deep, Long-Range Ecology Movement : A Summary se spíše přeceňuje, zůstává však pravdou, že články $z$ tohoto časopisu jsou asi nejvýznamnějším Naessovým příspěvkem hlubinné ekologii.

${ }^{15}$ Tzn. musí být dále například citován. Za ještě důležitější však považuji, že se základní myšlenky textu od okamžiku zveřejnění objevují v dílech jiných hlubinně ekologických autorů.

${ }_{16}$ Tzn. musí být dále například citován. Za ještě důležitější však považuji, že se základní myšlenky textu od okamžiku zveřejnění objevují v dílech jiných hlubinně ekologických autorů. 
4. Protože s rostoucí vyzrálostí se nevyhnutelně ztotožňujeme s ostatními, ,já' se rozšiřuje a prohlubuje, ,vidíme sebe v ostatních'. Sebeuskutečnění je znemožňováno, je-li znemožňováno sebeuskutečnění těch, s nimiž se ztotožňujeme. Láska k sobě usiluje o překonání této překážky tím, že pomáhá v sebeuskutečnění ostatním podle pravidla ,žij a nechej žít'. A tak vše co může být dosaženo altruizmem - svědomitým morálním ohledem $\mathrm{k}$ ostatním - může být dosaženo - a ještě umocněno - rozšířením a prohloubením nás samých...

Z hlediska ekofilosofie je hlavní toto: potřebujeme ekologickou etiku, jestliže však budou lidé pocitovat, že nesobecky omezují, nebo dokonce obětují své zájmy proto, aby ukázali svou lásku k prrírodě, bude to z dlouhodobého hlediska pravděpodobně nespolehlivý základ pro ekologii. Avšak skrze širší identifikaci, skrze opravdovou sebelásku, skrze lásku ke svému rozšířenému a hlubšímu Já mohou začít chápat, že ochrana přírody je jejich vlastním zájmem."17

Začínám analýzou ontologických východisek textu. Naess se, stejně jako Gándhí, proklamativně hlásí k dualizmus překonávající formě "ontologického" realizmu. Metafyzické Já je všezahrnující a jediné, stejně jako Gándhího átmán. ${ }^{18}$ Jak nepřímo vyplývá z textu a prímo z dalších textů A. Naesse - tato jednota není postavena na základě materiální podobnosti, stejného kódu či stejné strukturní informace. Je svojí bytostnou povahou duchovní a emocionální. ${ }^{19}$ Jenže - jak vidíme přímo v textu, takováto jednota předpokládá sice neexistující, ale reálný dualizmus já a Já. Je-li svět jednotný na základě metafyzického Já, kterého Ize dosáhnout, je nutné vyjít od „já" a toto „já" protikladné k „Já" musí reálně existovat. A stejně tak, je-li mimo-racionální poznávání a "ztotožnění" správnou formou poznání, musí být racionální poznávání nedokonalé, špatné, matoucí. Takže i u Naesse přetrvává jistá forma dualizmu - a to ne nepodobná té u M. Gándhího. Tento reálný svět, tak jak jej racionálně poznáváme, není skutečným světem. Skutečný je svět, ve kterém pouze „spontánní zkušeností máme přímý přístup k tomu, co je skutečné", ${ }^{20}$ skutečný svět je svět metafyzického Já, proti kterému stojí „neskutečný" svět já s malým "j". Tento Naessův "reálný" dualizmus je přitom - jak vyplývá z výše popsaného - prítomný $v$ ontologické i gnozeologické rovině. Stručně řečeno: ontologickým východiskem tohoto Naessova textu, a nejen jeho, je rozdělení skutečnosti na skutečnost falešnou, nesprávnou, neexistující a pravou, správnou a ontologicky jedině reálnou.

17 Je to úvodní část článku Sebeuskutečnění : ekologický přístup k bytí ve světě - viz Naess, A. Sebeuskutečnění : ekologický přistup k bytí ve světě. In Myslet jako hora : Shromáždění všech bytostí. 1. vyd. Prešov : Abies, 1993, s. 25, 26, 29. ISBN 80-88699-01-0.

18 Lze doložit u mnoha dalších Naessových textů. Např. v článku Heidegger, Postmodern Theory and Deep Ecology říká Naess doslova: „neexistuje žádné ontologické vákuum mezi já a ne-já, lidskostí a př́rodou" či v článku Ztotožnění jako zdroj hlubinně ekologických postojů "může být dosažena duchovní jednota s nejvyšším celkem, se ,světem', a to v širším a hlubším smyslu než je obvyklé". Viz Naess, A. Heidegger, Postmodern Theory and Deep Ecology. The Trumpeter. 1997, roč. 14, č. 4. ISSN 0832-6193. a Naess, A. Ztotožnění jako zdroj hlubinných ekologických postojů. In Závod s časem: texty z morální ekologie. 1. vyd. Praha : Torst, 1996. s. 88. ISBN 80-85639-70-X.

19 O tom Naess explicitně píše také ve čtvrté kapitole své životopisné knihy Is It Painful to Think?: Conversations with Arne Naess - The Cabin of Crossed Stones. V kapitole pojednává kromě popisu svého dlouhého nebezpečného samotářského života na hoře Tvergastein - ke kterému přiměl i svoji manželku,

a který trval bezmála půl století - také o tzv. gestaltech a nemateriální podstatě ontologických objektů. Viz Naess, A., Rothenberg, D. Is It Painful to Think? : Conversations with Arne Naess. 1. vyd. London : University of Minnesota Press, 1993. ISBN 0-8166-2151-9.

${ }^{20} \mathrm{Viz}$ 'I say that in spontaneous experiences we have direct access to what is real [...] In spontaneous experiences things appear without "effort", perhaps the Heideggerian terminology is helpful: phenomena are "self-luminous"'. Pasáž nalezneme $v$ článku: Naess, A. Heidegger, Postmodern Theory and Deep Ecology. The Trumpeter. 1997, roč. 14, č. 4. ISSN 0832-6193. 
A nyní přejděme k rozboru mentální struktury a emocionálních map textu. Aktorem výše uvedeného textu je čtenář, široké Já, úzké ego a příroda. Emocionální průsečíky, centra textu se váží ke třem aktorům, ke dvěma z nich pak velmi silně. Široké Já reprezentované sociálním, ekologickým a metafyzickým Já je spojeno s těmito emocionálně nabitými slovy: dostatečně a všestranně vyzrálí, cesta ke zralosti, od samotného počátku můžeme být $v$ přírodě, z přirody a pro přírodu, mnohem bohatší, rozšiřuje a prohlubuje, opravdovou sebelásku, skrze lásku. Naopak úzké ego je reprezentováno těmito emocionálně zabarvenými výrazy: úzké, nespolehlivý. Naess tedy alespoň v této ukázce distribuuje emocionální centra jednostranně. Přičemž - a to pro něj na rozdíl od typických fundamentalistů bude příznačné - spíše do své emocionální argumentace zapojuje kladná emocionálně laděná slova než naopak. U Naesse vidíme jistou Ihostejnost k reálnému světu, a to nejenom v ontologické rovině. Naess říká, že širší identifikace skrze opravdovou sebelásku, skrze lásku k svému rozšířenému a hlubšímu Já bude $v$ ochraně prírody účinnější než altruizmus. Nemá pro to jediný důkaz a ani jej nevyžaduje. Je to tedy text směřující k fundamentalistickému postoji. ${ }^{21}$ Aktor čtenář sice dostává na výběr pouze mezi bílou a černou, mezi skutečným a neexistujícím, mezi hodnotným a ne príliš hodnotným, ale tato volba je předestřena prímo a bez pokusư o manipulaci. ${ }^{22}$ A jaká jsou východiska prvního Naessova textu?

Každý člověk stojí před volbou mezi úzkým egem a širokým Já.

Volba směrem ke zralosti, rozšíření a prohloubení nás samých, směrem k bohatšímu životu vede přes široké Já.

Širokého Já můžeme dosáhnout mimo-racionální identifikací, ztotožněním.

Volba Širokého Já zároveň umožní dlouhodobou ochranu přírody.

Příroda a Široké Já jsou úzce spojeny.

Z hlediska formální analýzy textu můžeme konstatovat, že Naessův text je srozumitelný i přístupný. Jeho logická konzistence je spíše problematická - mnohde jde o tvrzení bez dưkazu, které nahrazuje právě emocionální působení.

Přejděme $\mathrm{k}$ dalšímu textu: ${ }^{23}$

„Klíčovým termínem ekosofie Stana Rowa, který nenalezneme např́klad v Ekosofii T, je ,významnost'. At' již umístíme smysl ,nejvyššího významu' kamkoliv, budou se na stejném místě nacházet také naše etické hodnoty. ,Pokus založit náš etický zájem o ekosféru na základě inside-out konceptu, tedy tak, že začneme se sebe-významností a postupujeme k významnosti lidské rasy, může dočasně ulevit našemu svědomí, ale bude to polibek smrti pro divokou přírodu.'

21 Problémem je samož̌ejmě skutečnost, že jsme vybrali pouze část Naessova textu, nicméně tato část skutečně směřuje $\mathrm{k}$ fundamentalizmu a fakt, že Naess má i výrazně proti-fundamentalistické části svých textů na tom nic nemění. Jen dokazuje, že náš předpoklad o jisté - dokonce přiznávané rozporuplnosti Naessovy filozofie byl namístě.

${ }^{22}$ Nepovažujeme-li za manipulaci již samo rozvrstvení emocionálních map.

${ }^{23}$ Vybírám text Legend, Deprived And Also College Students. Tento text na první pohled nesplňuje zadaná kritéria významného textu - vyšel až v roce 2001, neovlivnil hnutí jako jiné podstatné a nepoužité texty, jeho obsah jej mírou závažnosti řadí až do druhé, či spíše třetí roviny. Nicméně je to podle mého názoru nejreprezentativnější text pro odhalení podstatného rysu všech Naessových textů. Jak uvidíme dále, zastupuje $v$ tomto smyslu části textů jako: Self-Realization an Ecological Approach to Being in the World, The Place of Joy in a World of Fact, Deep Ecology in the Line of Fire, How Should Supporters of the Deep Ecology Movement Behave in Order to Affect Society and Culture. Je totiž názorným vyjádřením té části Naessova díla, která je pro-racionální, pro-osvícenská, proliberální. Zde ještě podotýkám, že obě části Naessova díla nejsou separované podle jednotlivých článků, příspěvků do sborníků, knih. Obě části Naessovy filozofie se sice neorganicky a nekompatabilně, ale přece prolínají téměř celým Naessovým dílem. 
K porovnávání ,vzájemné významnosti' připomíná Rowe toto: ,Co je zdrojem života buňky? Zivé orgány, které tvoří její bezprostřední okolí. Co je zdrojem života orgánů? Živý organizmus, $v$ němž jsou zakomponovány. Co je zdrojem života organizmu? Okolní živé ekosystémy a globální ekosféra.' S odkazem na J. K. Feiblemana Rowe ř́ká: ,Mechanizmus každé úrovně je založen na nižších úrovních (na svých součástech), zatímco smysl každé úrovně se nalézá $v$ úrovni bezprostředně nadřazené ( $v$ celku)'. To Rowa vede $k$ velmi radikální formulaci role lidí na Zemi. Zdá se, že Rowův koncept i způsob myšlení a cítění je od konceptu mého a nejspíše i mnohých dalších hlubinných ekologů velmi odlišný. Ale dokonce i na základě, který sám mohu nazvat prístupem významnost významnosti, můžeme Rowa zabudovat do našeho konceptu [...]

Otázka, má-li věc, organizmus či systém hodnotu o sobě, pak závisí na významu dané věci, organizmu, systému. Velmi nemocný člověk či krysa má velmi malý význam. Vztahy $v$ rodině jsou více či méně významné $v$ rámci systému, ale etické normy a hodnoty mají jen velmi málo co do činění s významem. Etika se zabývá spišse zodpovědností a péćí. A - samozřejmě - povinností, která je jen nepř́mo spojena s otázkou systému významností.

Běžná definice hlubinně ekologického hnutí byla často kritizována za opomíjení vnitřní hodnoty jedinců - či jinak individuálního - ve prospěch systémů, obecného, například ve prospěch ,rozkvětu všech životních forem'. Můj vlastní přístup je založen na záměně bodu 1 a 2 obecně přijatých osmi zásad hlubinné ekologie, takže kladu na první místo jednotlivé žijící bytosti a na druhé zdraví a rozkvět života. To je rozdíl oproti opačnému směru, tak jak jej Stan Rowe navrhuje. Ale mnozí přijmou spiše jeho směřování, a já jsem přesvědčený, že je slučitelné s pozicí podporovatele a člena hlubinně ekologického hnutí a co víc, že přispívá $\mathrm{k}$ vyjádření pohledu přispívajícího $\mathrm{k}$ zmírnění destruktivity lidského vlivu na prírodu".24

K ontologickým východiskům tohoto Naessova textu se čtenáŕ dostává velmi obtižně, nejenže nejsou uvedeny $v$ textu, ale Naess $k$ nim dokonce ani neprímo neodkazuje. Snad jen $v$ závěru mưžeme nalézt určité přiznání dualizmu kultury a prírody, ovšem $v$ úplně jiném smyslu než např. u Šmajse, ${ }^{25}$ a také $v$ jiném smyslu než $v$ jeho prvním textu. Vše co můžeme o ontologických východiscích tohoto textu říci je, že „hluboko" za textem je jistý dualizmus, který ovšem bezprostředně obsah neovlivňuje.

Daleko zajímavější bude samotná analýza textu. Ještě před samotným určením aktorů textu chci poznamenat, že text o textu přináší do způsobu rozboru jistou duplicitu. Počet aktorů se počtem „vložených" textů násobí a proto se i zde setkáváme s aktory, kteři jsou navzájem paralelní. ${ }^{26}$ Tato nesnáz ovšem není nepřekonatelná. Aktoři spojení s náplní sporu - ekosféra, lidé či ve vyšší míře obecnosti jednotlivosti a systémy jsou totiž aktory vzhledem $\mathrm{k}$ textu bezvýznamnými. Text nepojednává o ničení př́rody člověkem, text pojednává o možnostech př́stupu k bránění tomuto ničení. A proto nemohou být primárními aktory textu aktoři textu vloženého.

${ }^{24}$ Viz anglický text Naess, A. Legend, Deprived And Also College Students. The Trumpeter. 2001, roč. 13 , č. 1. ISSN 0832-6193.

25 Šmajsův ontologický dualizmus bude pro srovnání s hlubinně ekologickým velmi užitečný. Šmajs skutečnost také dělí na dva řády, ovšem toto rozdělení vychází z reálně ověřitelných rozdílů - jiná a jinak uchovávaná vnitřní informace. Je přece významným rozdílem, pokud tvrdíte, že svět je rozdělen na já a Já, na átmán a bráhma a toto rozdělení je naprosté, úplné, definitivní a pokud prokážete jinou vnitřní informaci dvou ontických řádů. První tvrzení je totiž ontologicky naprosto neukotvené, at se již v textech hlubinných ekologů píše cokoliv o jeho "hluboké", "spontánní povaze. ${ }^{26} \mathrm{~V}$ tomto konkrétním prípadě jsou aktory jednak ekosféra, lidé a ničení ekosféry, jednak Naessův koncept hlubinné ekologie, koncept hlubinné ekologie Stana Rowa a v pozadí mnohost a čtenáři textu. 
Aktorem našeho textu - a z výše uvedeného vyplývá, že jej musíme hledat v závěrečném odstavci - je přístup Arne Naesse, př́stup Stana Rowa a hlubinná ekologie. Emocionální centra textu - vzhledem k aktorưm - téměř chybějí. Výjimkou je kladné "zmírnění destruktivity" nebo negativní "opomíjení vnitřní hodnoty jedinců" - jež je však zmírňováno „rozkvětem všech životních forem". ${ }^{27 Z}$ hlediska emocionality textu nacházím oproti textu jednu významnou odlišnost. Naess zde aktory nerozděluje, ale spíše vyvažuje a dokonce slučuje. Text nám - v první i druhé rovině - říká, že rozdílné přístupy a definice hlubinné ekologie jsou nejenom možné, ale i žádoucí. $V$ rovině východisek to Ize formulovat následovně:

Existují různé výklady hlubinné ekologie, které se navzájem liší.

Je na každém, aby si jeden z nich vybral nebo vytvořil.

Tento proces je nejen možný, ale i žádoucí.

Naess se tu výrazně od první ukázky proměnil. Poselstvím jeho textu je podpora individuální zvláštnosti, a dále až proklamativní, ale upřímná tolerance a absence emocionálního zneužívání. Jak je to možné?

Každý kdo četl více než dvě nebo tři ukázky Naessova díla ví, že nejde o náhlou proměnu Naessova přístupu ani o pozvolné prorůstání jednoho přístupu do druhého. Obě tváře Naesse jsou př́tomné ve většině jeho textů. Podívejme se na jeho polemiku s C. A. Bowersem, ${ }^{28}$ M. Zimmermanem, ${ }^{29}$ J. B. Callicottem, ${ }^{30}$ či dokonce M. W. Levisem. ${ }^{31}$

V polemice S C. A. Bowersem, ve které jde o použíání tzv. pre-reflektivních podvědomých metod ovlivňování, Naess nakonec dospívá k závěru, že jeho vlastní vědomá a argumentovaná - propagace vlídnosti k přírodě prostřednictvím vlídnosti k našemu Já je docela dobře slučitelná s Bowersovým přístupem a že záleží na každém, kterou z nich si vybere. ${ }^{32}$ A stejně tak v polemice s Zimmermanem - která je svojí větší částí vlastně diskuzí o postmoderně - Naess přijímá „hodnoty" postmoderny a píše, že je až na jisté excesy - slučitelná s postojem hlubinné ekologie. Z hlediska střední analýzy textu je polemika $s$ Bowersem i Zimmermanem $v$ těchto pasážích shodná $s$ vybraným úryvkem.

A dokonce $v$ polemice $s$ výrazným odpůrcem hlubinné ekologie Martinem W. Lewisem ${ }^{33}$ Naess tento př́stup uplatňuje. Píše doslova - a neironicky - "Lidé jako Lewis

27 Jak Ize vidět na tomto příkladě, emocionální centra textu se mohou navzájem rušit.

$28 \mathrm{Viz}$ Naess, A. How Should Supporters of the Deep Ecology Movement Behave in Order to Affect Society and Culture. The Trumpeter. 1993, roč. 10, č. 3. ISSN 0832-6193.

29 Viz Naess, A. Heidegger, Postmodern Theory and Deep Ecology. The Trumpeter. 1997, roč. 14, č. 4. ISSN 0832-6193.

30 Viz Naess, A. The Deep Ecology "Eight Points" Revisited. In Deep Ecology for the 21st Century: Reading on the Philosophy and the Practice of New Environmentalism. Boston : Shambhala, 1995. s. 215-217. ISBN 1-570-62049-0.

31 Viz Naess, A. Deep Ecology in the Line of Fire. The Trumpeter. 1995, roč. 12, č. 3. ISSN $0832-6193$. 32 To je - podle mého názoru - jedna z nejtemnějších stránek Naessovy vstřícnosti. Bowersem prosazovaná metoda - a existují místa, kde se k ní Naess hlásí - je čirá esence fundamentalizmu v PR stylu. Naessovy poznámky o tom, že je potřeba protivníkům pomáhat řešit jiné problémy a zvát je na kávu prostě zastírají, že v případě přímých, nátlakových akcí jde o moc. Ovládání něčí vůle nezmírní podání čerstvé kávy. Naess dưsledně ve své snaze slučovat a zahrnovat přijímá i nesmírně nebezpečné tendence. To není podle mého názoru morálně ospravedlnitelné.

33 M. W. Lewis patři do stejné kategorie autorů jako např. Beckmann či Arnold. Viz např. BECKMANN, P. Eco-Hysterics and the Technophobes. Boulder : Golem Press, 1973.; ARNOLD, R. At the Eye of the Storm : James Watt and the Environmentalists. Chicago : Regnery Gateway, 1982. ISBN 0-89526634-2. Jsou to odpưrci (nejen) radikálního environmentalizmu a obhájci konceptu volného trhu. Lewis je však značně originální. Jeho koncept spočívá na oddělení kultury a přírody, na zprůmyslnění 
jsou potřeba", stejně jako lidé, které označuje za neextrémistické přívržence hlubinné ekologie. Také oni přispějí k formulování cílů a samozřejmě budou trvat na tom, že kvalita lidského života nebude redukována (Lidskost kvưli lidskosti!") 34

Zdá se tedy, že Naess je - at' již vědomě či nevědomě - z hlediska analýzy textu nesmírně rozporuplným autorem. Na jedné straně se přiklání k fundamentalistickým koncepcím, na straně druhé však nedokáže opustit hodnoty vycházející z humanizmu a plurality. Oba prvky se pak prolínají ve většině textů.

Z hlediska třetí části analýzy se jedná o text srozumitelný a přistupný, logicky nekonzistentní.

A dostávám se k poslednímu analyzovanému Naessovu textu³5:

„Dospěl jsem k názoru, že je někdy žádoucí jednoduše vypsat tendence a př́istupy charakteristické pro příslušníky a příznivce hlubinně ekologického hnutí [...]

1. Využívání skromných prostředků. Vyhýbání se nadbytečných prostředků k tomu, abychom dosáhli cíle.

2. Tendence preferovat aktivity prímo sloužící hodnotám o sobě a mající vnitřní hodnotu. Vyhýbání se aktivitám, které jsou spíše prostředkem, nemajícím žádnou hodnotu o sobě nebo jsou př́liš daleko od podstatných cílů.

3. Anti-konzumní styl a minimalizace osobního vlastnictví. Tento negativní př́stup plyne z bodu 1 . a 2 .

4. Snaha udržovat a zvyšovat citlivost a ocenění věcí, kterých je dostatek pro všechny.

5. Absence nebo velmi nízká úroveň ,neofilie' - lásky ke všemu novému, protože je to nové. Oceňování starých, již používaných věcí.

6. Snaha o život bohatý na situace hodnotné samy o sobě a též snaha o činnost raději než pouhou zaneprázdněnost.

7. Uznání etnické a kulturní jinakosti lidí, odpor vưči chápání cizího jako ohrožení.

8. Zájem o situaci ve třetím a čtvrtém světě a snaha vyhnout se hmotnému životnímu standardu, který se přiliš liší a převyšuje životní standard chudých. (Globální solidarita v životním stylu)

9. Ocenění životního stylu, který je možné univerzálně sdílet, a který není očividně neudržitelný bez (páchání) křivd (bezpráví) na ostatních lidech a formách života.

zemědělství a ponechání kulturního kultuře a přírodního přírodě. Urbanizované lidstvo by pak mělo saturovat svoje potřeby pouze prostřednictvím rozvinutého průmyslu.

34 Viz NAESS, A. Deep Ecology in the Line of Fire. The Trumpeter. 1995, roč. 12, č. 3. ISSN $0832-$ 6193.

35 Jedná se o text Deep Ecology and Lifestyle, který je souborem pravidel pro chování hlubinných ekologů. Je příznačný z hlediska dalšího vlivu na hnutí a myslitele hlubinné ekologie a vhodně tak doplňuje předcházející dva texty. Viz NAESS, A. Deep Ecology and Lifestyle. In Deep Ecology for the 21st Century: Reading on the Philosophy and the Practice of New Environmentalism. Boston: Shambhala, 1995, s. 259-261. ISBN 1-570-62049-0. 
10. Snaha získat hloubku a bohatou zkušenost spíše než intenzitu.

11. Ocenění a snaha - vždy, když je to možné - získat smysluplnou práci spíše než práci pouze pro naplnění životních potřeb.

12. Žít plným (nikoliv komplikovaným) životem, snaha zažít tolik pozitivních zážitků, kolik jen je to v daném čase možné.

13. Rozvoj vztahů $v$ komunitě (Gemeinschaft) spíše než ve společnosti (Gesellschaft).

14. Podpora, nebo participace $v$ primární produktivní sféře $-v$ drobném zemědělství, malých lesnických firmách, v rybářství.

15. Snaha o uspokojování životních potřeb spíše než tužeb. Odpor vưči tendenci ,jít na nákupy' jako rozptýlení nebo terapie. Zmenšení celkového počtu vlastněných věcí, upřednostňování starých, použitých, ale dobře udržovaných věcí.

16. Snaha o život $v$ př́rodě spíše než jen její ,navštěvování - vyhýbání se turizmu (s občasným využitím turistického zařízení).

17. Snaha o to pohybovat se v nechráněné přírodě ,lehce a bez následkư'.

18. Tendence ocenit všechny životní formy spíše než vybírat pouze ty, které považujeme za krásné, pozoruhodné či úzce chápáno užitečné.

19. Nikdy nepoužívat živé bytosti pouze jako prostředky. Stálé uznání jejich vnitřní hodnoty a dưstojnosti - i když je použijeme jako zdroje.

20. Jestliže nastane konflikt v obhajobě zájmů psů a koček (a dalších domácích zvírat) a divokých zvířat - tendence postavit se na stranu těch divokých

21. Snaha bránit místní ekosystémy, ne jen jednotlivé formy života. Chápání místních komunit jako součástí ekosystému.

22. Odsuzování nepřiměřeného zneužívání přírody nejen jako zbytečné, nesmyslné a odsouzeníhodné, ale také jako drzé, kruté, odporné a zločinné - ovšem bez odsuzování lidí zodpovědných za toto zneužívání.

23. Snaha jednat rezolutně a bez zbabělosti $v$ konfliktech, ale důsledné dodržování principů nenásilí ve slovech i skutcích.

24. Podíl na a podpora přímých, nenásilných akcí, jestliže ostatní možnosti selhávají.

25. Vegetariánství, úplné nebo částečné."

Také tento třetí text považuji za reprezentativní. Nikoliv ontologickými východisky, která ani zde neuvádí Naess prrímo. Nikoliv logickou konzistencí, která je asi nejspornější ze všech tři uvedených textů, ale svým podtextem, skrytým poselstvím a jeho východisky. Naess totiž tímto textem nesděluje pouze sumu příkladů hlubinně ekologického chování, ale sugeruje čtenáři dualizmus dobra a zla argumentovaný v rovině emocionální a intuitivní. A to je nesmírně nebezpečné. Ale zde je zapotřebí důkazu.

Nejprve určím aktory textu. Jsou to "život podle nauky ekologického hnutí", "život normální pro naši západní společnost" a čtenář textu. Aktoři v textu přímo uvedeni nejsou a již to poukazuje na možnost manipulace. Tuto hypotézu pak jednoznačně potvrzuje emocionální strukturace textu. K aktoru „život podle nauky ekologického hnutí prířazuje Naess tyto emocionální slova: mající vnitřní hodnotu, citlivost, skutečně cenných, bohatý 
život, vstřícnost (transformovaná do komplikovaného vyjádření v bodě 7., hloubka a bohatá zkušenost, smysluplná práce, plný život, komunita, život $v$ přirodě, lehkost, krásná a cenná, hodnota dưstojnosti, statečnost. K aktoru „život normální pro naši západní společnost" přiřazuje Naess aktory jako: žádná hodnota, neofilie, pouhá zaneprázdněnost, intenzita místo hloubky, pouhé naplnění životních potřeb, společnost, pouhé rozptýlení, používání jiných jako prostředků, zneužívání přírody. Aktor čtenář je emocionálně neutrální a zdá se nacházet $v$ pozici volby mezi těmito dvěma alternativami. Jenže v textu - a to ani v textu obklopujícím uvedený text a v Naessových textech obecně36 - nejsou uvedeny důkazy ani analýzy potvrzující tuto emocionální distribuci. Naess se odvolává na intuici ${ }^{37}$, na emocionální pocity, ovšem ty necítí čtenář „izolovaně", "spontánně", jak píše Naess, ty jsou vyvolány distribucí emocionálních center. Naess tedy nejprve vyvolá Vaše kladné emoce $v$ souvislosti $s$ volbou aktora "život podle nauky ekologického hnutí a záporné emoce v souvislosti s volbou „život normální pro naši západní společnost" a poté nechá působit Vaši intuici. A to je - at' již tak učinil záměrně či nikoliv - nebezpečná manipulace 38

Východiska takového textu Ize určit následovně.

Existují dva přístupy ke světu: „hlubinně ekologický” a „běžný”.

Přístup "hlubinně ekologický" je dobrý a správný, přístup "běžný" je špatný a nesprávný.

Každý necht' si vybere podle svého určení - dobrý člověk ten „hlubinně ekologický” zlý ten „běžný".

Tento text je fundamentalistický, je sofistikovaný (at' již to autor zamýšlel či nikoliv) a tedy i manipulativní.

Jeho logická konzistence je velmi sporná ( $v$ bodech 5, 16, 20 naprosto zřejmě) - což je způsobeno jednak vzájemným míšením vrstev různého stupně abstrakce či špatně určeným vyplýváním. Text je srozumitelný a přistupný.

Jak Ize poznat z analýzy tři vybraných textů, je základním filozofickým názorem Arne Naesse podvojný dualizmus. Dualizmus ontologický, formulovaný v koncepci já - Já a dualizmus gnoseologický artikulovaný pomocí pojmů vcítění (jakožto mimoracionálního poznávání) a empiricko-deduktivního poznávání. Tento podvojný dualizmus, patrný zejména $v$ textu jedna a tři doplňuje silné Naessovo ocenění hodnoty plurality a svobody názoru ostatních lidí (zcela zřejmé z druhého analyzovaného textu). Potvrzuje se tak názor vyjádřený $v$ předchozích částech mé práce. Zklamání z vývoje evropské kultury, které stojí v základu Naessovy filozofie, stejně jako filozofický koncept, který je vyjádřením tohoto zklamání, však nepochází z doby vzniku hlubinné ekologie (začátek 70. let), ale z první půle dvacátého století. Hlubinná ekologie je pokračováním Gándhího, Heideggerova a Zapffova filozofického postoje, nikoliv dialogem s novou levicí či postmodernisty. A stejně tak ocenění plurality a odmítnutí zcela iracionálního přístupu $v$ gnoseologických

\footnotetext{
36 U Naesse samozřejmě ještě nalézáme výjimky, tendence je však jasná.

37 Vypsat všechny Naessovy odkazy na intuitivní poznání není možné, uved'me si proto jen několik příkladů: NAESS, A., Rothenberg, D. Is It Painful to Think? : Conversations with Arne Naess. 1. vyd. London : University of Minnesota Press, 1993. ISBN 0-8166-2151-9.; NAESS, A. Heidegger, Postmodern Theory and Deep Ecology. The Trumpeter. 1997, roč. 14, č. 4. ISSN 0832-6193.; NAESS, A. Mountains and Mythology. The Trumpeter. 1995, roč. 12, č. 4. ISSN 0832-6193.; NAESS, A. Ztotožnění jako zdroj hlubinných ekologických postojů. In Závod s časem : texty z morální ekologie. 1. vyd. Praha : Torst, 1996. s. 87. ISBN 80-85639-70-X.

38 Naess podle všeho nebyl záměrným manipulátorem, jeho texty však na mnoha místech manipulativní jsou.
} 
otázkách je plodem Naessova vývoje let dvacátých a třicátých, nikoliv paralelním vývojem s filozofií 70 . let.

\section{Závěr}

Ve své práci jsem se pokusil ukázat, že dosavadní interpretace Naessovy hlubinné ekologie, založené na přesvědčení o Naessově důsledném humanistickém postoji nejsou z pohledu rozboru Naessových textů udržitelné. Naess, který navazuje na autory jako $M$. Gándhí či M. Heidegger prosazuje v ontologických i gnoseologických otázkách zvláštní formu podvojného dualizmu. Tento dualizmus odmítá rozum jako důležitý nástroj poznání a individuálního člověka jako zásadní hodnotu. Důraz klade naopak na mimo-racionální formy poznávání a subjekt stojící mimo i nad já.

Součástí Naessova pohledu na svět je však, na rozdíl od již zmíněného M. Gándhího, silný důraz na názorovou pluralitu, který Naessovi znemožňuje přijmout důsledný náboženský fundamentalizmus tak typický pro hlubinné ekology druhé a třetí generace.

Naesse proto vidím jako značně rozporuplnou postavu. Jeho dílo totiž kromě všech zásadních znaků hlubinné ekologie (antiosvícenství, antihumanizmus, antiliberalizmus) nese též rys, který jej z rámce hlubinné ekologie jednoznačně vyděluje. Tímto rysem je, podle mého názoru, ocenění plurality a hodnoty svobodného dialogu.

Navíc, jak vyplývá z druhé, třetí a nepřímo i čtvrté části textu, je Naessův filozofický názor podstatně starší a genealogií svého vzniku i podstatnější než jeho vlastní hlubinná ekologie - Ekosofie T.

\section{Literatura}

- Arnold, R. (1982). At the Eye of the Storm : James Watt and the Environmentalists. Chicago: Regnery Gateway.

- Beckmann, P. (1973). Eco-Hysterics and the Technophobes. Boulder. Boulder, Colo: Golem Press.

- Binka, B. (1999). Několik kritických poznámek k „hlubinné ekologii” Arne Naesse. Universitas, 4, 43-47.

- $\quad$ Deep ecology Edited by M Tobias (1985). San Diego: Avant Books.

- Devall, B. (1988). Simple in Means Rich in Dnes : Practicing Deep Ecology. Salt Lake City : Peregrine. Salt Lake City: Smith Books.

- Devall, B., \& Sessions, G. (1985). Ecology : Living as if Nature Matterd. Salt Lake City. Salt Lake City: Peregrine Smith Books.

- Drengson, A. (1995). The Deep Ecology Movement. The Trumpeter. The Trumpeter, 12(3),

- Fox, W. (1992). Arne Naess : A Biographical Sketch. The Trumpeter, 9(2),

- Langlais, R. (1995). Living in the World : Mountain Humility, Great Humility. In Deep Ecology for the 21 st Century : Reading on the Philosophy and the Practice of New Environmentalism. : Boston : Shambhala,

- Librová, H. (1994). Pestří a zelení : Kapitoly o dobrovolné skromnosti. Brno: Veronica.

- Manes, C. (1990). Green Rage : Radical Environmentalism and the Unmaking of Civilization. Boston: Little, Brown and Copany. 
- Naess, A. (1984). A Defense of the Deep Ecology Movement. Environmental Ethics, 6(3), 265-270.

- Naess, A. (1988). Deep Ecology and Ultimate Premisis. The Ecologist, 18(4/5), 128-131.

- Naess, A. (1995). Deep Ecology in the Line of Fire. The Trumpeter, 12(3),

- Naess, A. (1989). Ecology, Community and Lifestyle. Cambridge: Syndicate of Press of the University of Cambridge.

- Naess, A. (1974). Gándí and Group Conflict : An Exploration of Satyagraha - Theoretical Background. Oslo: Universitetsforlaget.

- Naess, A. (1965). Gándhí and the Nuclear Age. Totowa: Bedminister.

- Naess, A. (1997). Heidegger, Postmodern Theory and Deep Ecology. The Trumpeter, 14(4),

- Naess, A. (1993). How Should Supporters of the Deep Ecology Movement Behave in Order to Affect Society and Culture. The Trumpeter, 10(3),

- Naess, A. (1984). Intuition, Intristic Value, and Deep Ecology : Comments on an Article by Warwick Fox. The Ecologist, 14(5/6),

- Naess, A. (2001). Deprived And Also College Students. The Trumpeter, 13(1),

- Naess, A. (1993). Sebeuskutečnění: Ekologický př́stup k bytí ve světě. In Myslet jako hora : Shromáždění všech bytostí. Prešov: Abies.

- Naess, A. (1989). The Deepness of Deep Ecology. Earth First!. The Radical Environmental Journal, 10(2),

- Naess, A. (2005). The Selected Works of Arne Naess. Dordrecht. Dordrecht: Springer.

- Naess, A. (1992). The Three Great Movements. The Trumpeter, 9(2),

- Naess, A. (1985). The world of concrete contents. Inquiry, 28(1-4), 417-428. Retrieved from http://www.tandfonline.com/doi/abs/10.1080/00201748508602059 http://dx.doi.org/10.1080/00201748508602059

- Naess, A. (1996). Ztotožnění jako zdroj hlubinných ekologických postojů. In Závod s časem : Texty z morální ekologie. .

- Naess, A., \& Rothenberg, D. (1993). Is It Painful to Think? : Conversations with Arne Naess. London. Minneapolis: University of Minnesota Press.

- Naess, A. (1995). Mountains and Mythology. The Trumpeter, 12(4),

- Seed, J. (1993). Uslyšet v sobě hlas plačící Země. In Myslet jako hora : Shromáždění všech bytostí. Prešov: Abies.

- Seed, J., Macy, J., Fleming, P., \& Naess, A. (1988). Thinking Like a Mountain : Towards a Council of all Beings. Philadelphia, PA: New Society Publisher.

- Sessions, G. (1995). Ecocentrism and the Antropocentric Detour. In Deep Ecology for the 21st Century : Reading on the Philosophy and the Practice of New Environmentalism. Boston: Shambhala.

- Skolimowski, H. (1992). Living Philosophy : Eco-Philosophy as a Tree of Life. : London : Arkana. 
- Zimmerman, M. E. (1994). Contesting Earth's Future : Radical Ecology and Postmodernity. Los Angeles: University of California.

\section{Recenzní posudky (slovní hodnocení příspěvku)}

Recenzent 1 - posudek I. části textu publikované v minulém čísle:

Pavel Skála - Katedra filozofie a dějin přírodních věd Přírodovědecké fakulty UK.

„Za hlavní přínos příspěvku považuji otevření problematiky myšlenkového (resp. filozofického) pozadí hlubinné ekologie, což je téma u nás, nakolik je mi známo, téměř nezpracované. Autorovo pojednání se mi zdá být poměrně zajímavé a hluboké."

\section{Recenzent 2 - posudek I. části textu publikované v minulém čísle:}

Arnošt Novák - Katedra sociální a kulturní ekologie Fakulty humanitních studií UK

"Autor se v textu zabývá filozofickými východisky Arneho Naesse, který bývá často označován za zakladatele hlubinné ekologie. Nejprve shrnuje dosavadní interpretace filozofie Arneho Naesse, aby v další části článku předestřel zázemí, jak myšlenkové, tak i životní z něhož Naess vychází. Tato dobře zpracovaná část textu je důležitá pro pochopení Naessova díla a zejména pro pochopení jeho rozporuplnosti, jak ji poměrně přesvědčivě autor $v$ textu dokládá. Používá $\mathrm{k}$ tomu metody analýzy tří textů. Tady mohl vyvstat problém $s$ jejich výběrem, nicméně autor si toho byl vědom a výběr se snažil odůvodnit. Autor prokázal značnou znalost Naessova díla, stejně tak i další relevantní literatury. Příspěvek je kvalitní a doporučuji jej k publikaci, protože přináší důležité podněty k diskuzi v oblasti radikální ekologie, či radikálního environmentalizmu."

\section{Recenzent 2 - posudek II. části textu publikované v tomto čísle:}

„Text doporučuji ke zveřejnění, protože po obsahové a formální stránce splňuje nároky odborného textu.

Autor ve druhé části textu o filosofovi Arne Naessovi analyzuje tři jeho texty, vnichž poukazuje na jistou jeho rozporuplnost vjeho myšlení. Autor prokázal poměrně důkladnou znalost Naessova díla, stejně jako i další relevantní literatury. Byl si také vědom problému tří textů určených kanalýze, a tento poněkud svévolný výběr se pokusil odůvodnit.

Příspěvek je kvalitní a doporučuji jej k publikaci, protože přináší důležité podněty k diskusi v oblasti radikální ekologie, či radikálního environmentalismu." 
Časopis Envigogika vydává Centrum pro otázky životního prostředí UK. Vývoj časopisu je podpořen projektem OP VK Mezioborová sít udržitelného rozvoje.

Více najdete na internetových stránkách projektu mosur.czp.cuni.cz
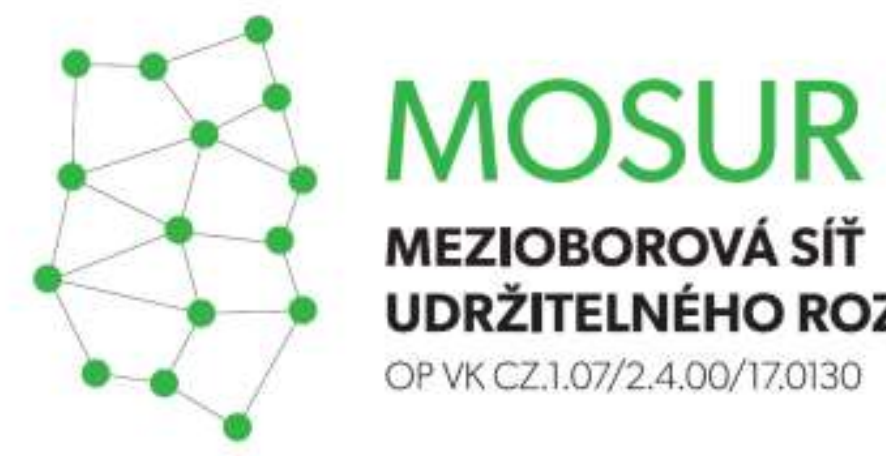

\section{MEZIOBOROVÁ SÍT} UDRŽITELNÉHO ROZVOJE

OP VK CZ.1.07/2.4.00/17.0130
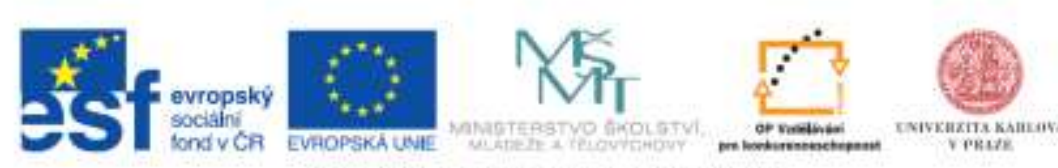

INVESTICE DO ROZVOUE VZDELAVANI 